Supporting Information for:

\title{
Critical Issues of Fluorinated Alkoxyborate- Based Electrolytes in Magnesium Battery Applications
}

\author{
Toshihiko Mandai*
}

Center for Green Research on Energy and Environmental Materials, National Institute for Materials Science (NIMS), 1-1 Namiki, Tsukuba, Ibaraki 305-0044, Japan

CORRESPONDING AUTHOR FOOTNOTES

Telephone: +81-29-860-4464, E-mail: MANDAI.Toshihiko@nims.go.jp 
(a)

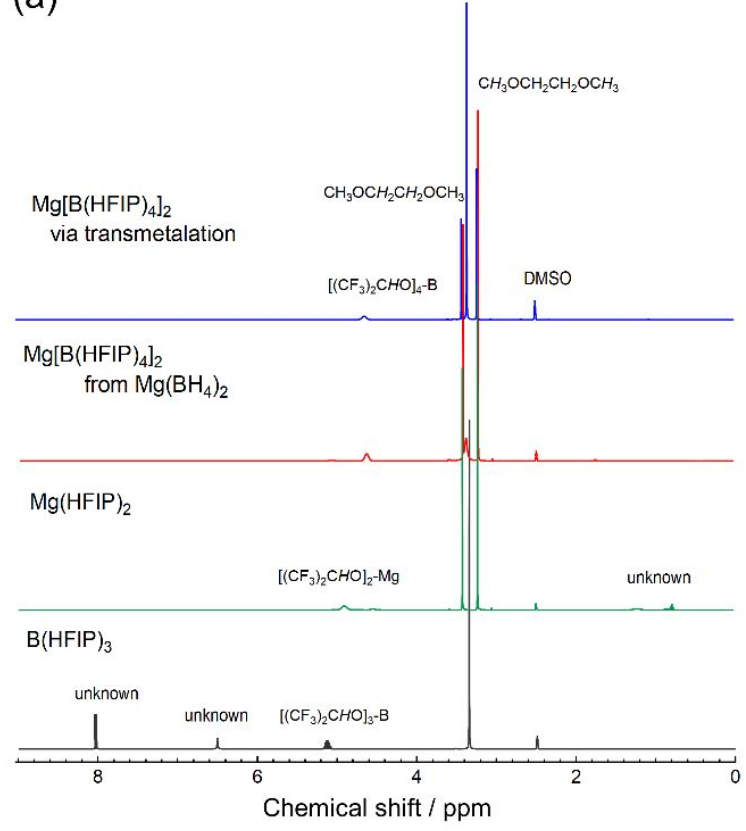

(b)

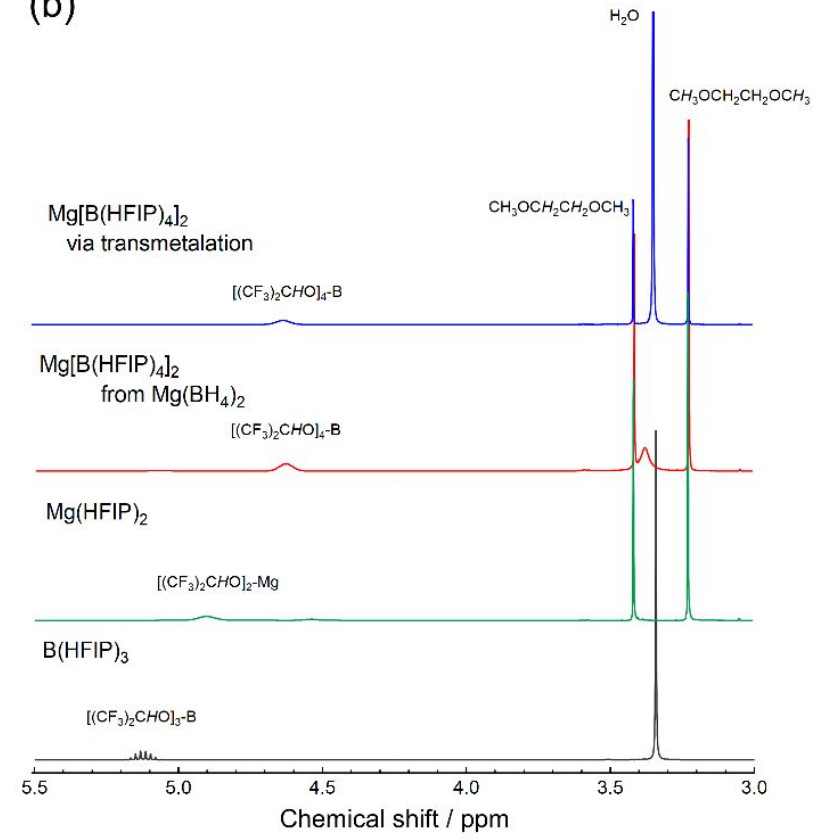

Figure $\mathrm{S} 1 .{ }^{1} \mathrm{H}$ NMR spectra of $\mathrm{Mg}\left[\mathrm{B}(\mathrm{HFIP})_{4}\right]_{2}$ synthesized via different procedures. The spectra of $\mathrm{Mg}(\mathrm{HFIP})_{2}$ and commercial $\mathrm{B}(\mathrm{HFIP})_{3}$ are also shown. (a) Full-range (0-9 ppm) of the spectra, (b) magnified figure in the range where peaks are severely overlapped (3-5.5 ppm).

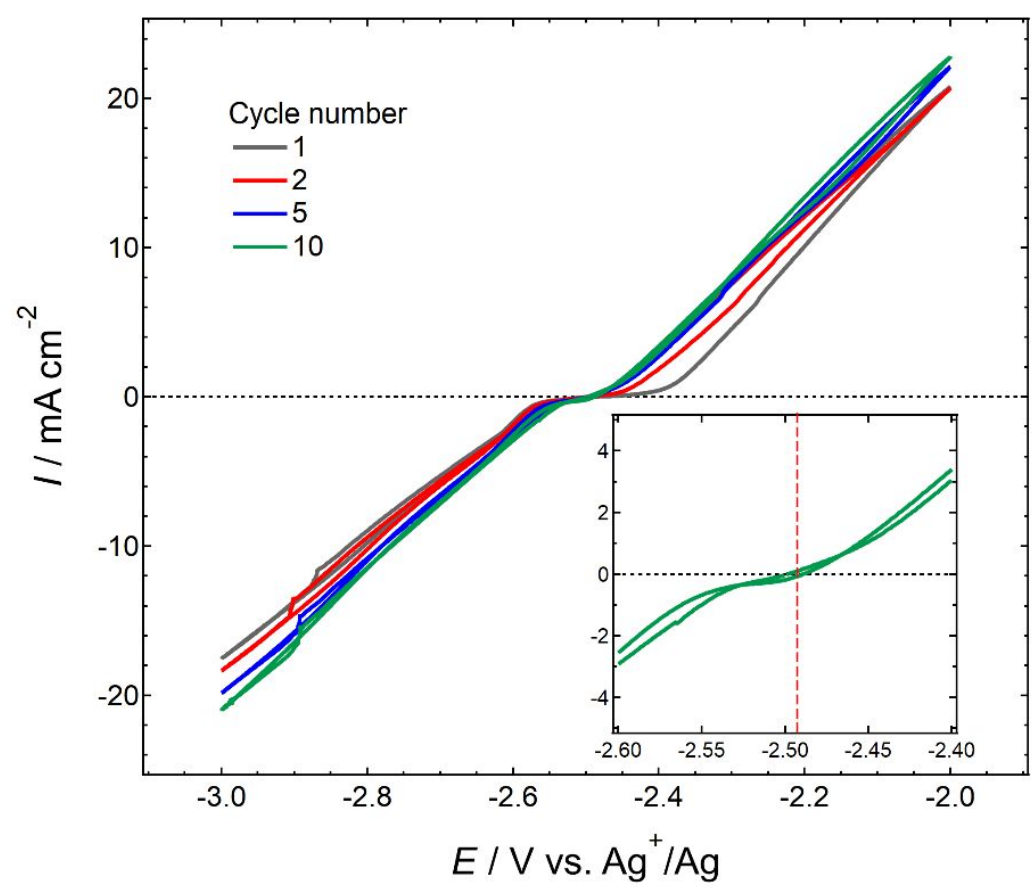

Figure S2. Cyclic voltammograms (CVs) of $0.3 \mathrm{~mol} \mathrm{dm}^{-3} \mathrm{Mg}\left[\mathrm{Al}(\mathrm{HFIP})_{4}\right]_{2} / \mathrm{G} 2$ recorded on $\mathrm{Mg}$ electrode at a scan rate of $10 \mathrm{mV} \mathrm{s}^{-1}$ and $30{ }^{\circ} \mathrm{C}$. The inset is the magnified figure of the $10^{\text {th }}$ cycle to determine the electrode potential of the $\mathrm{Ag}^{+} / \mathrm{Ag}$ reference used here. 


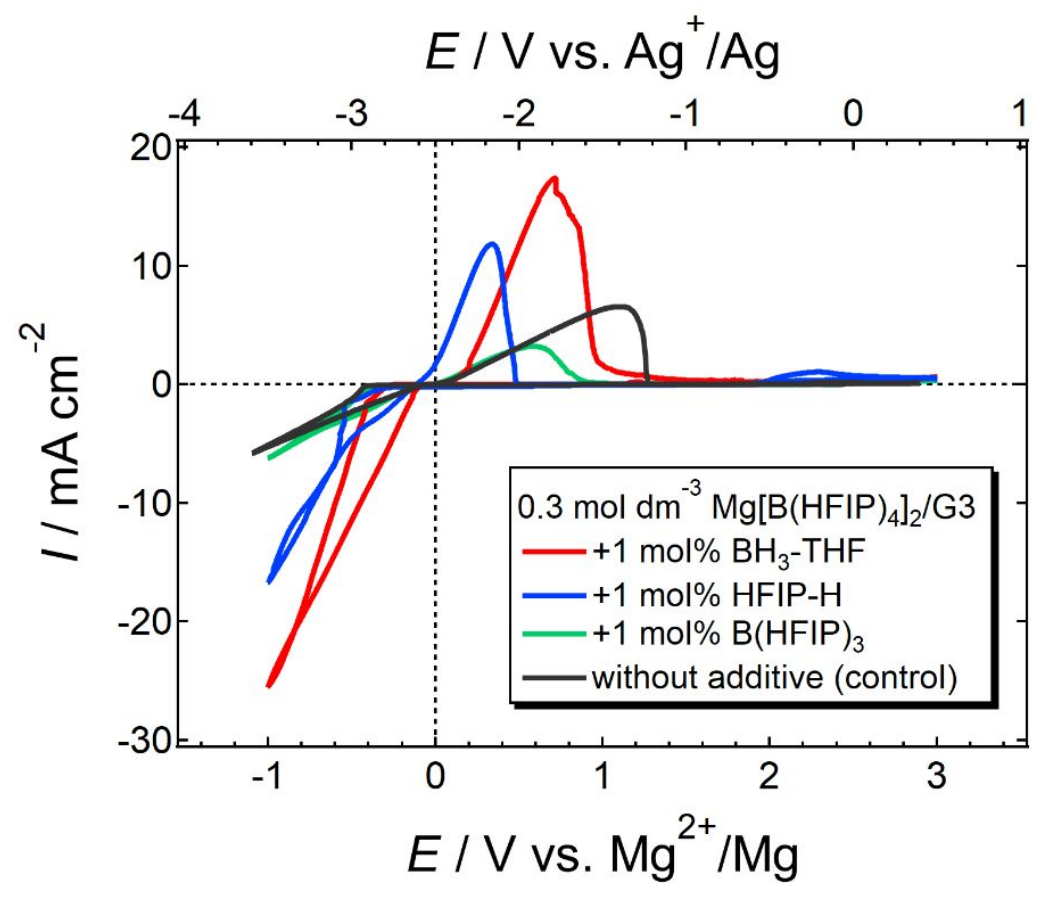

Figure S3. CVs of $0.3 \mathrm{~mol} \mathrm{dm}^{-3} \mathrm{Mg}\left[\mathrm{B}(\mathrm{HFIP})_{4}\right]_{2} / \mathrm{G} 3$ and those containing $1 \mathrm{~mol} \%$ of $\mathrm{BH}_{3}$-THF, HFIP-H, or $\mathrm{B}(\mathrm{HFIP})_{3}$ recorded on the Pt electrode at a scan rate of $10 \mathrm{mV} \mathrm{s}^{-1}$ and $30^{\circ} \mathrm{C}$.

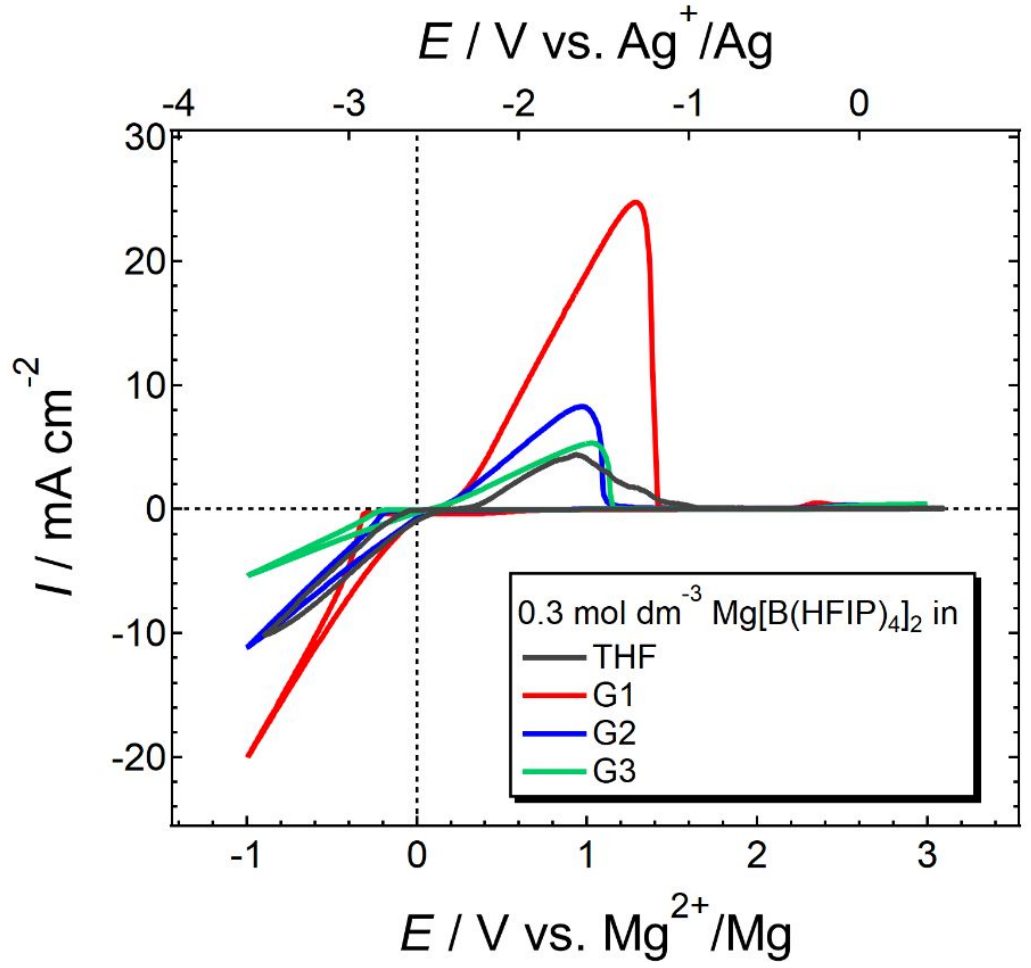

Figure S4. CVs of $0.3 \mathrm{~mol} \mathrm{dm}^{-3} \mathrm{Mg}\left[\mathrm{B}(\mathrm{HFIP})_{4}\right]_{2}$ dissolved in THF, G1, G2, and G3 recorded on the Pt electrode at a scan rate of $10 \mathrm{mV} \mathrm{s}^{-1}$ and $30^{\circ} \mathrm{C}$. 


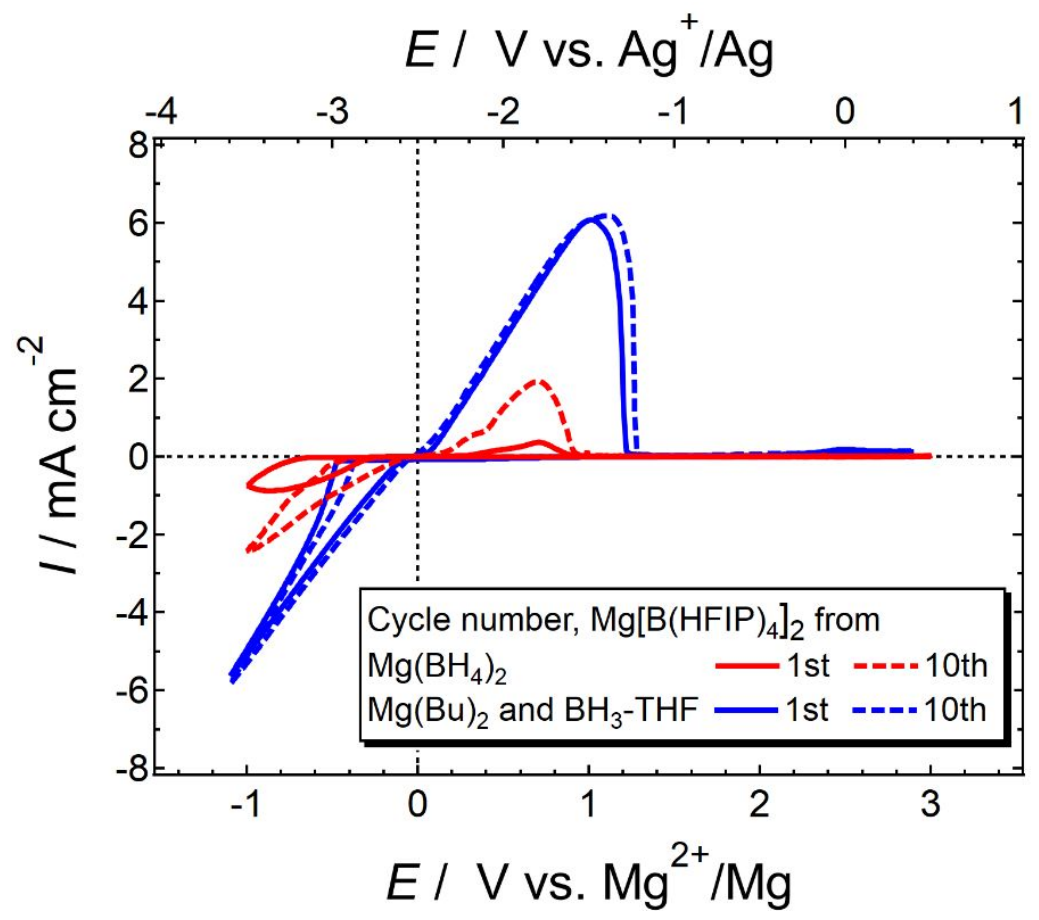

Figure S5. CVs of $0.3 \mathrm{~mol} \mathrm{dm}^{-3} \mathrm{Mg}\left[\mathrm{B}(\mathrm{HFIP})_{4}\right]_{2} / \mathrm{G} 3$ recorded on the Pt electrode at a scan rate of $10 \mathrm{mV} \mathrm{s}^{-1}$ and $30{ }^{\circ} \mathrm{C} . \mathrm{Mg}\left[\mathrm{B}(\mathrm{HFIP})_{4}\right]_{2}$ samples synthesized by different reagents were used.
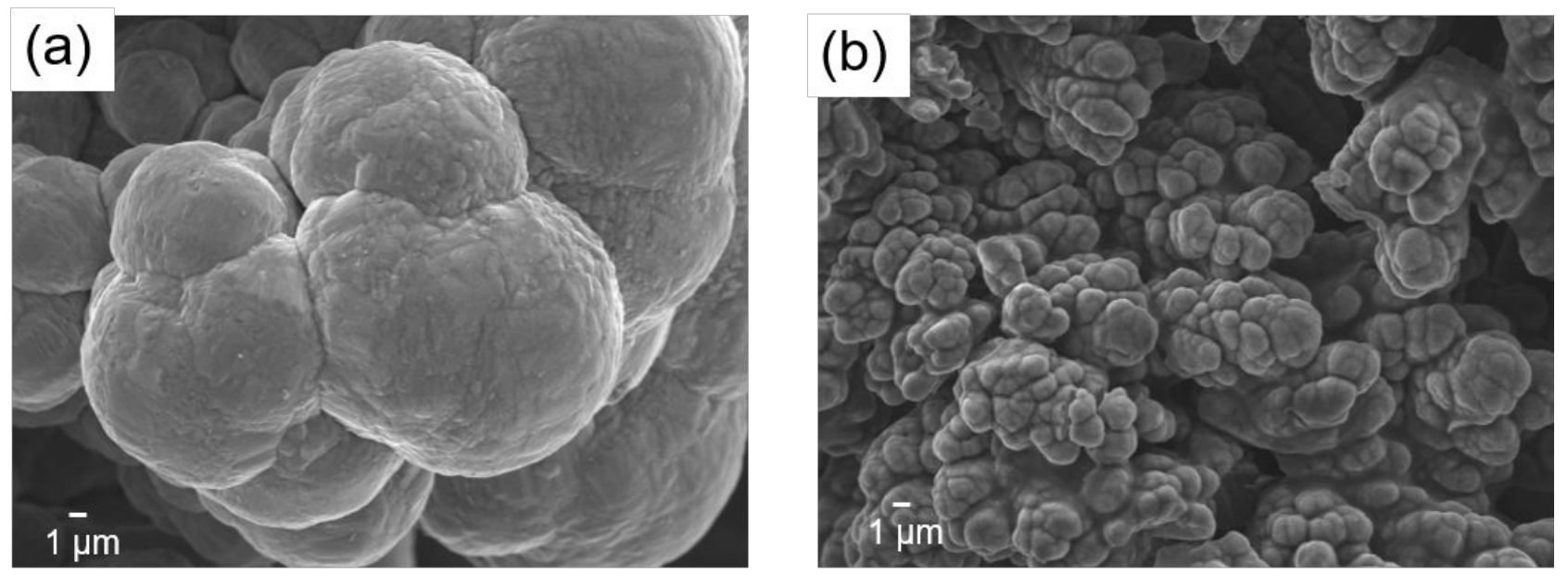

Figure S6. SEM images of the deposited magnesium obtained from $0.3 \mathrm{~mol} \mathrm{dm}^{-3} \mathrm{Mg}\left[\mathrm{B}(\mathrm{HFIP})_{4}\right]_{2} / \mathrm{G} 3$. $\operatorname{Mg}\left[\mathrm{B}(\mathrm{HFIP})_{4}\right]_{2}$ samples synthesized by (a) transmetalation and (b) dehydrogenation of $\mathrm{Mg}\left(\mathrm{BH}_{4}\right)_{2}$ were used. 

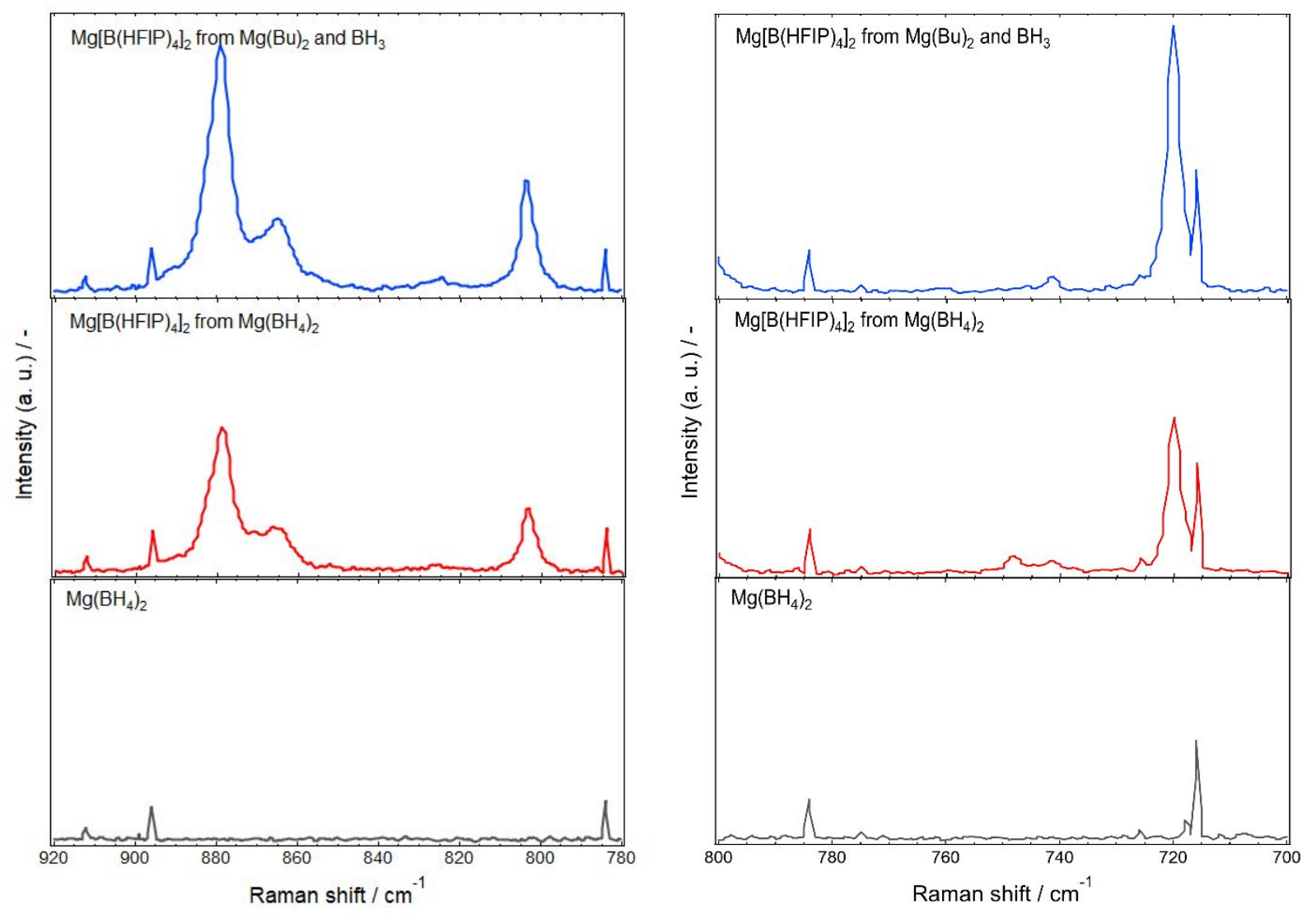

Figure $\mathrm{S} 7$. Raman spectra of $\mathrm{Mg}\left[\mathrm{B}(\mathrm{HFIP})_{4}\right]_{2}$ synthesized from different reagents measured at room temperature.

The spectra of $\operatorname{Mg}\left(\mathrm{BH}_{4}\right)_{2}$ were also included as a reference.

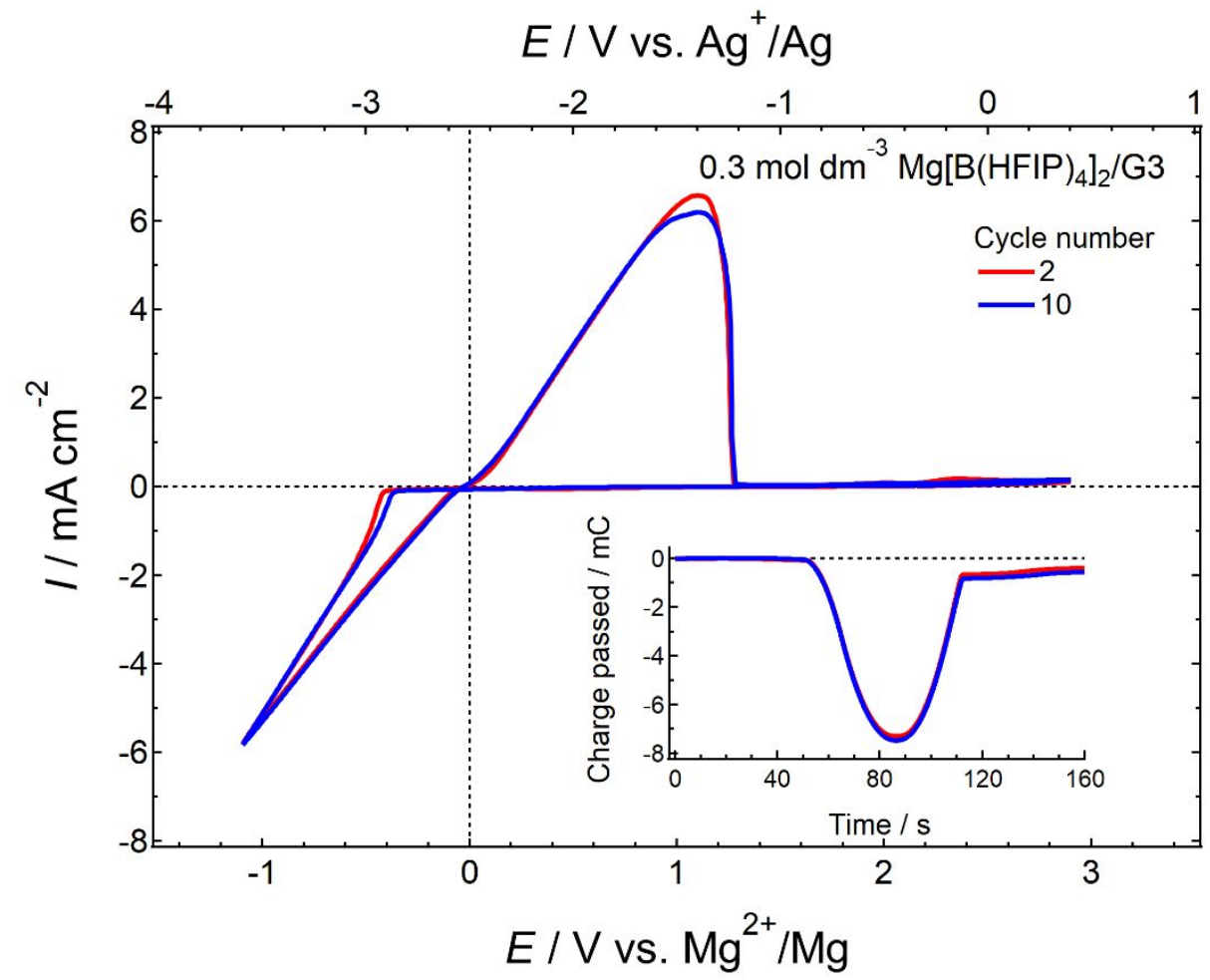

Figure S8. CVs of $0.3 \mathrm{~mol} \mathrm{dm}^{-3} \mathrm{Mg}\left[\mathrm{B}(\mathrm{HFIP})_{4}\right]_{2} / \mathrm{G} 3$ recorded on the Pt electrode at a scan rate of $10 \mathrm{mV} \mathrm{s}^{-1}$ and 
$30^{\circ} \mathrm{C}$. The inset displays the charge passed during cycling.

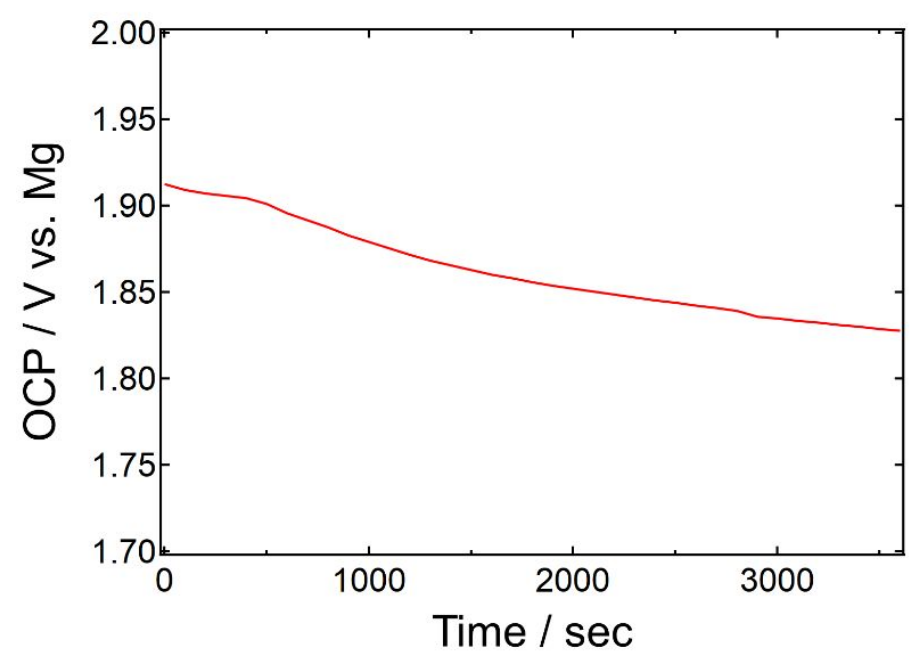

Figure S9. Time profiles of OCP for the $\left[\mathrm{Mg}\left|0.3 \mathrm{~mol} \mathrm{dm}^{-3} \mathrm{Mg}\left[\mathrm{B}(\mathrm{HFIP})_{4}\right]_{2} / \mathrm{G} 3\right| \mathrm{Pt}\right]$ cell held at $30^{\circ} \mathrm{C}$.
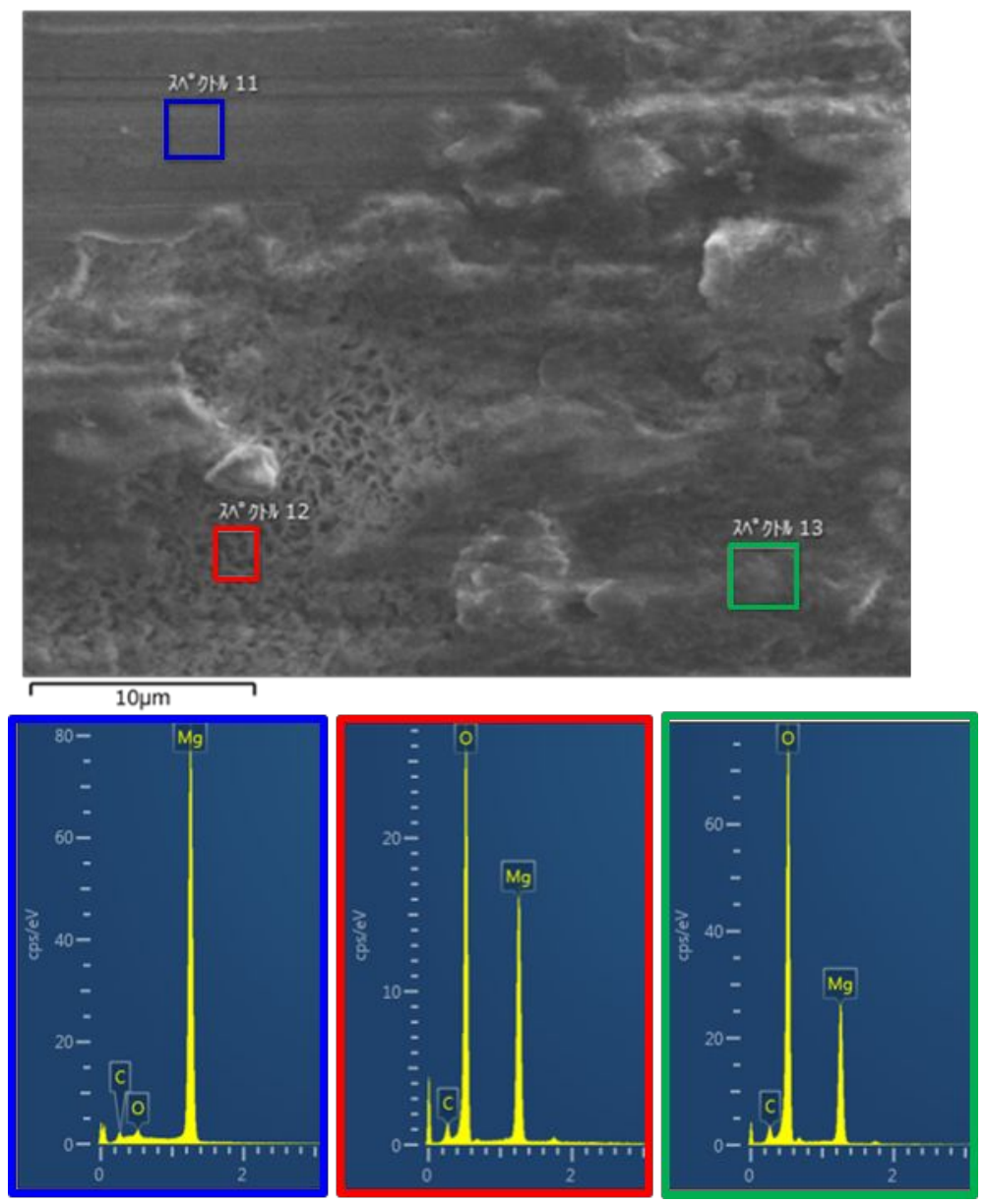

Figure S10. SEM images and EDX analysis on the selected area of magnesium metal soaked in $0.3 \mathrm{~mol} \mathrm{dm}^{-3}$ $\operatorname{Mg}\left[\mathrm{B}(\mathrm{HFIP})_{4}\right]_{2} / \mathrm{G} 3$ for 3 days at $30{ }^{\circ} \mathrm{C}$. 

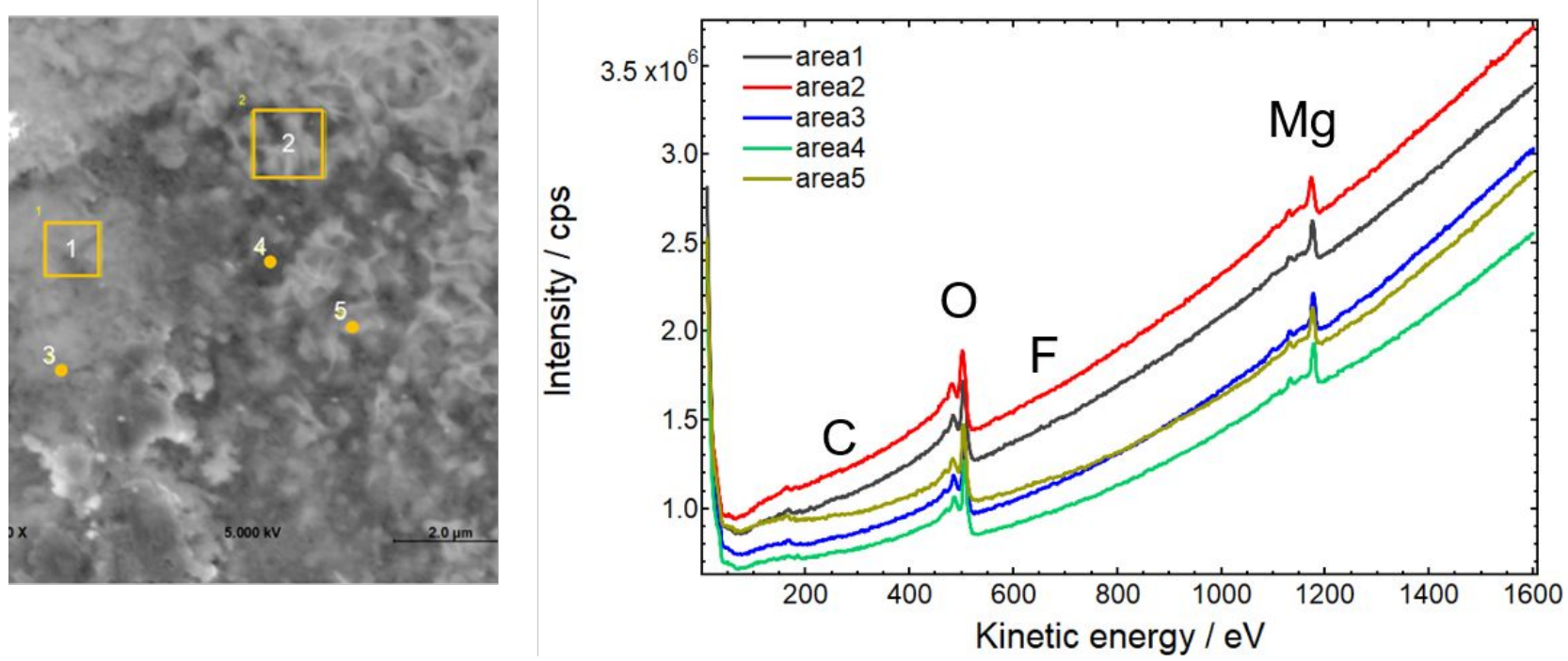

Figure S11. SEM image and corresponding AES spectra of magnesium metal soaked in $0.3 \mathrm{~mol} \mathrm{dm}^{-3}$ $\mathrm{Mg}\left[\mathrm{B}(\mathrm{HFIP})_{4}\right]_{2} / \mathrm{G} 3$ for 3 days at $30^{\circ} \mathrm{C}$.
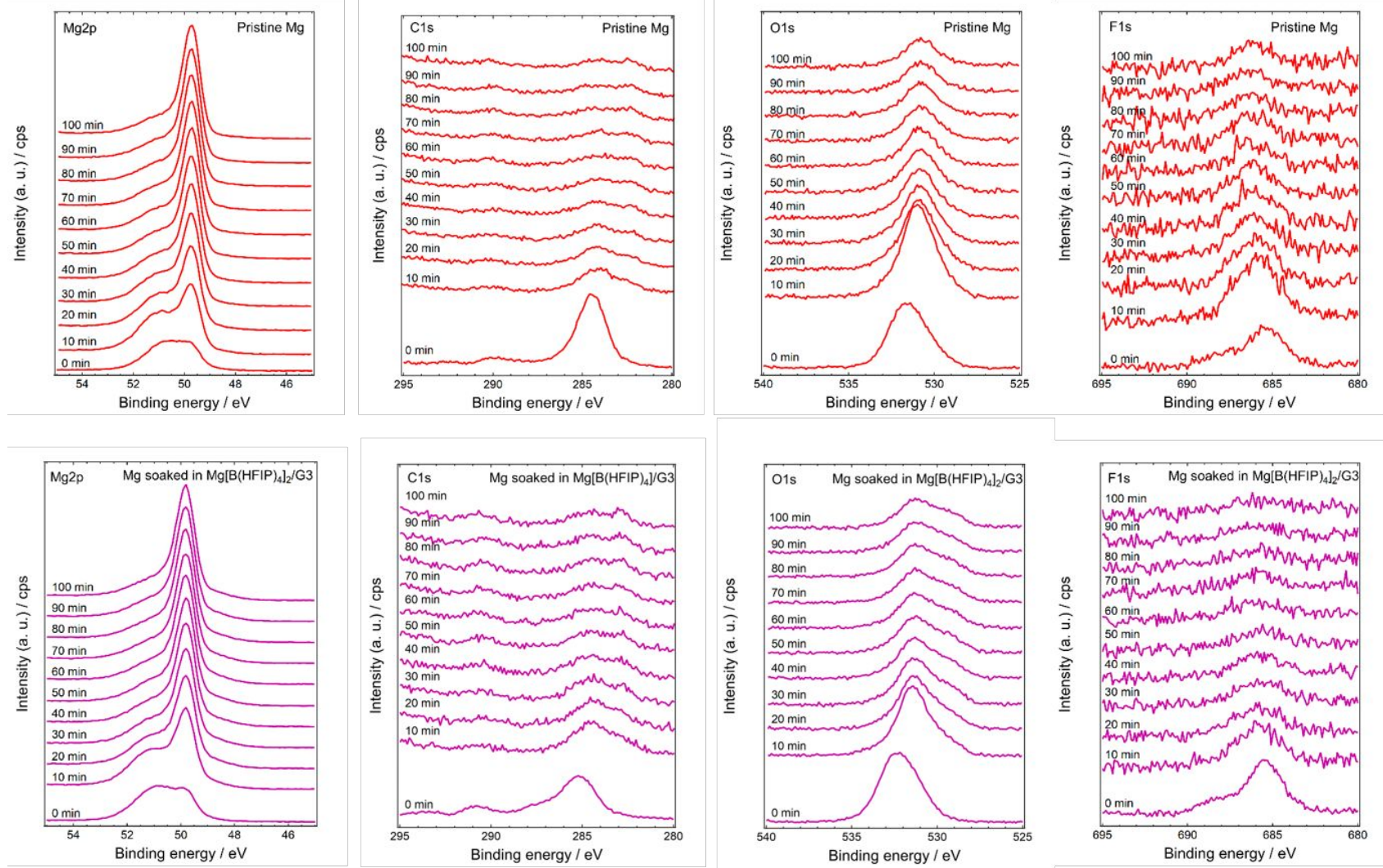

Figure S12. Depth profiles of XPS spectra of the non-treated pristine magnesium metal and metal soaked in 0.3 $\mathrm{mol} \mathrm{dm}{ }^{-3} \mathrm{Mg}\left[\mathrm{B}(\mathrm{HFIP})_{4}\right]_{2} / \mathrm{G} 3$ for 3 days at $30{ }^{\circ} \mathrm{C}$. 

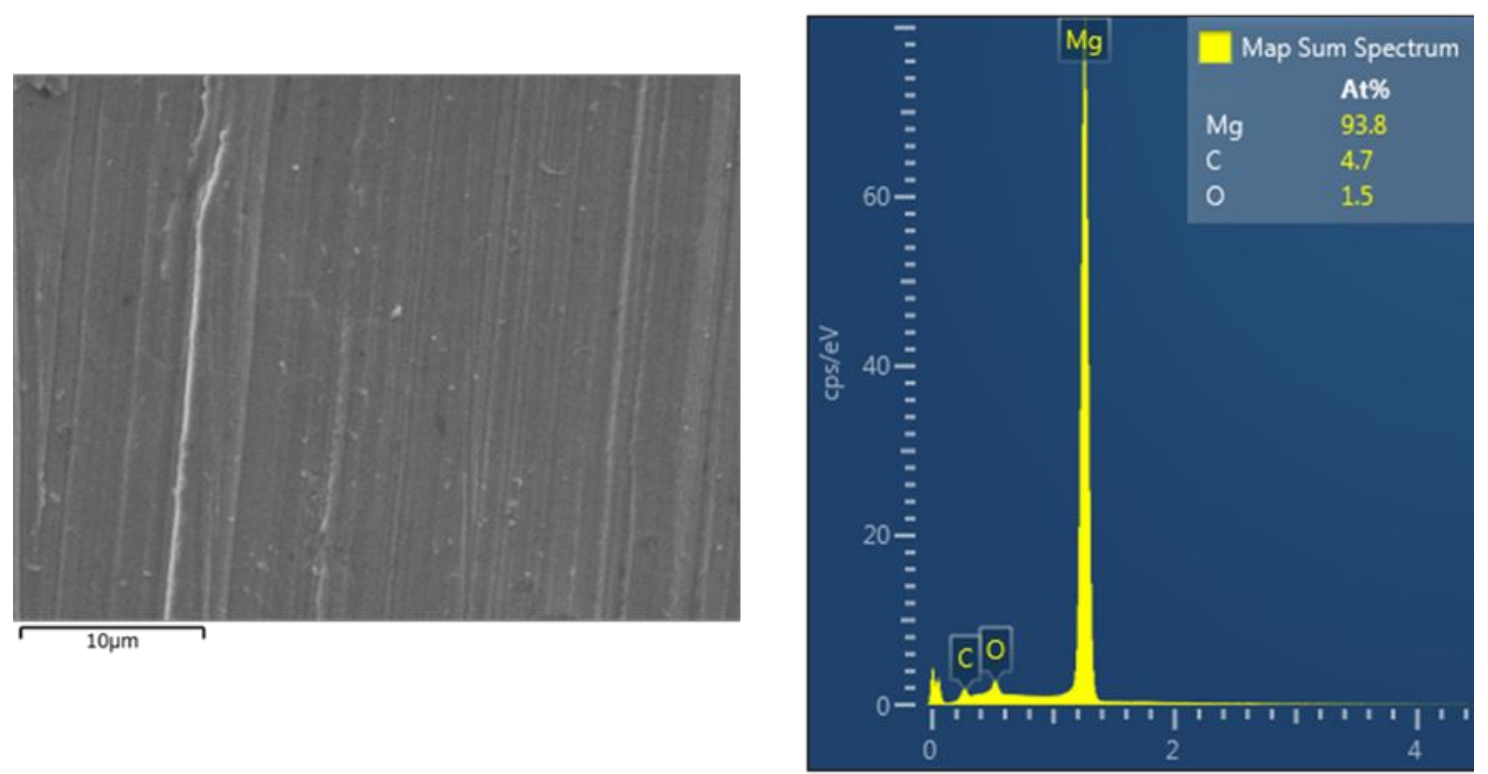

Figure S13. SEM and corresponding EDX mapping spectra of magnesium metal soaked in ca. $2 \mathrm{~mol} \mathrm{dm}^{-3}$ $\mathrm{C}_{2} \mathrm{H}_{5} \mathrm{MgCl} / \mathrm{THF}$ for 3 days at $30^{\circ} \mathrm{C}$.

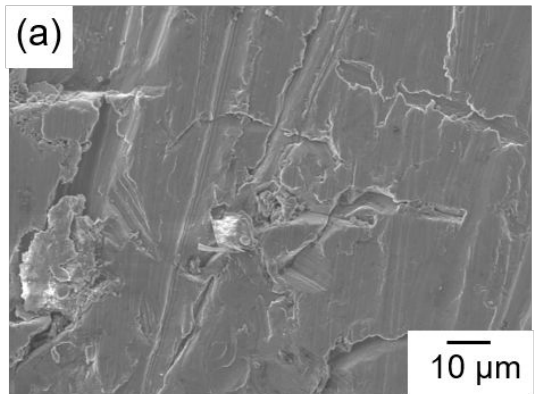

(b)

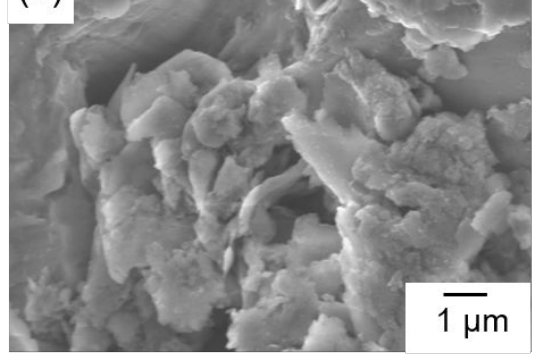

(c)

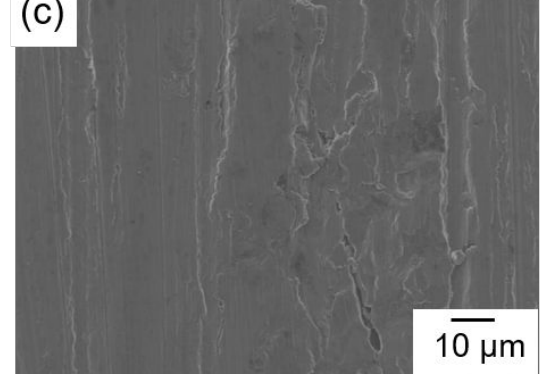

(d)

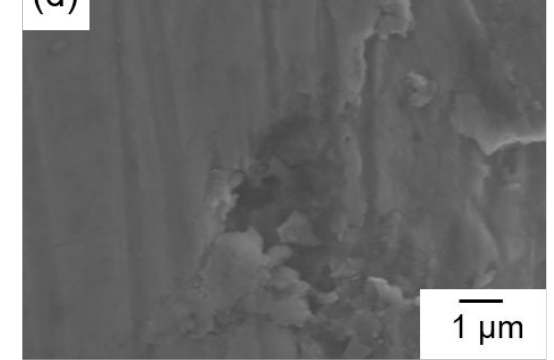

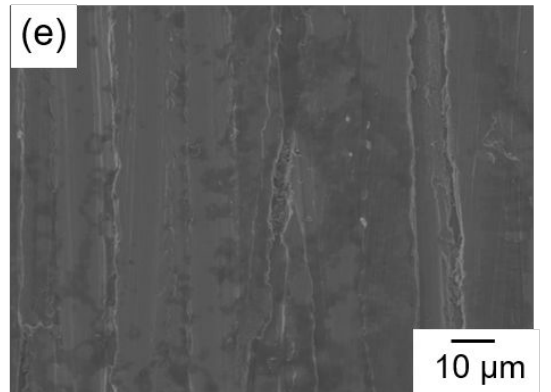

(f)

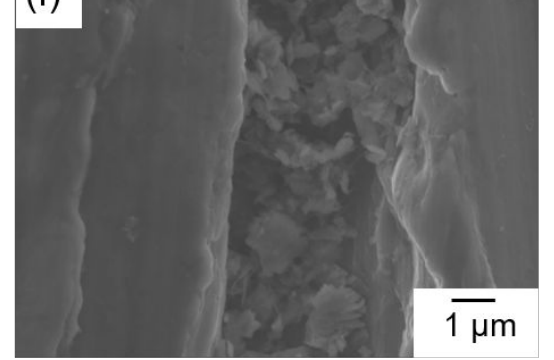

Figure S14. SEM images of the magnesium metals soaked in (a) and (b) 0.1 ; (c) and (d) 0.3 ; and (e) and (f) 0.5 mol dm ${ }^{-3} \mathrm{Mg}\left[\mathrm{B}(\mathrm{HFIP})_{4}\right]_{2} / \mathrm{G} 3$ for 1 day at $30{ }^{\circ} \mathrm{C}$. 

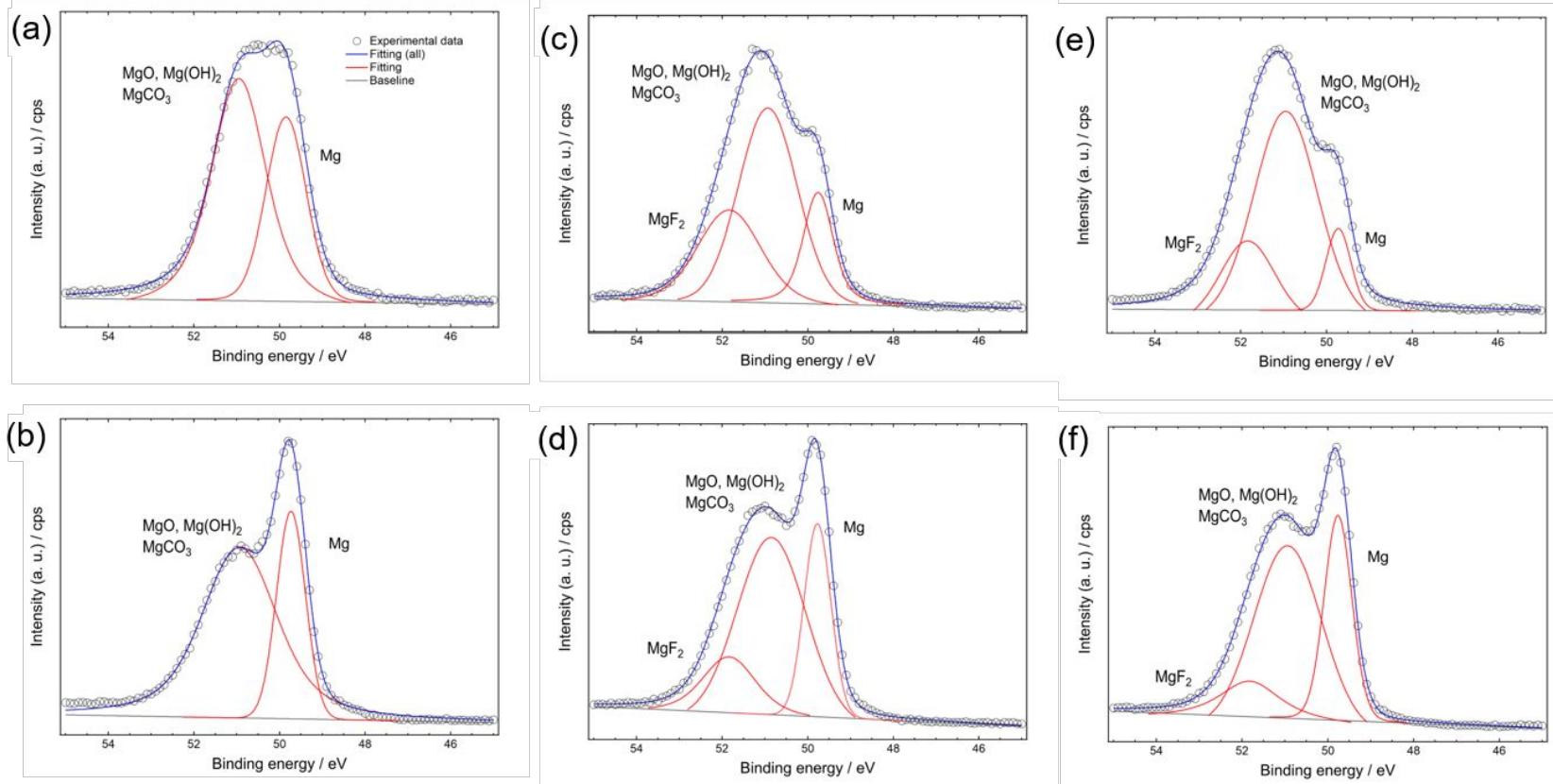

Figure S15. Mg 2p spectral deconvolution of (a) and (b) pristine magnesium; (c) and (d) pretreated magnesium; and (e) and (f) pretreated magnesium soaked in $0.3 \mathrm{~mol} \mathrm{dm}^{-3} \mathrm{Mg}\left[\mathrm{B}(\mathrm{HFIP})_{4}\right]_{2} / \mathrm{G} 3$. (a), (c), (e): Surface profiles; (b), (d), (f) depth profiles after $10 \mathrm{~min}$ of Ar beam sputtering. Pretreated magnesium has a contribution of $\mathrm{MgF}_{2}$ to the spectra.
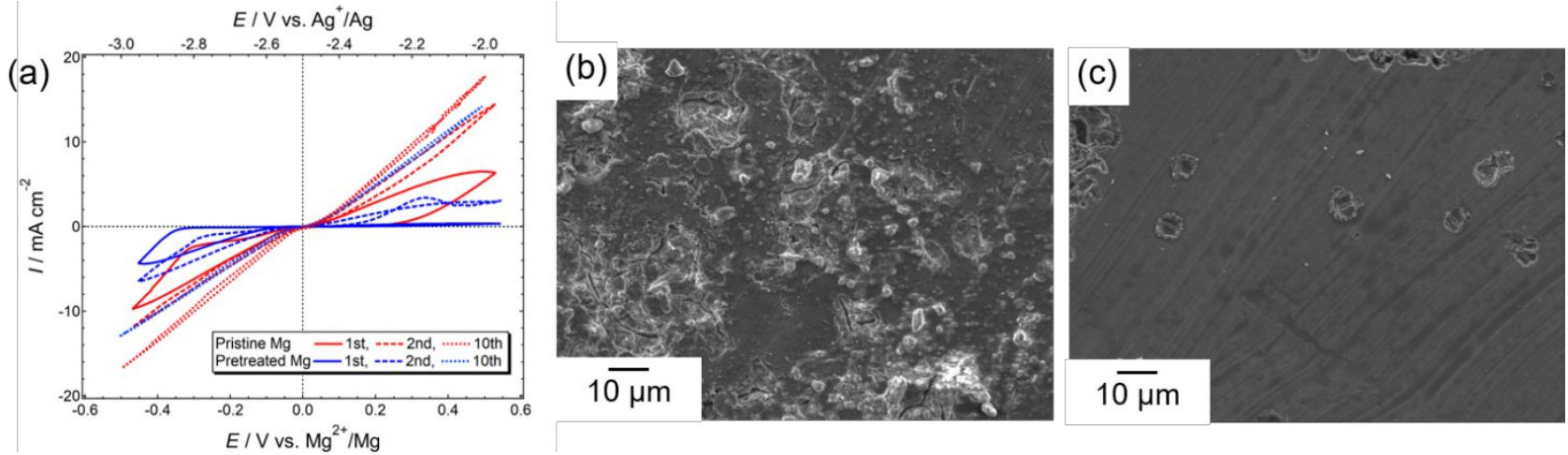

Figure S16. (a) CVs of pristine and pretreated $\mathrm{Mg}$ metal recorded in $0.3 \mathrm{~mol} \mathrm{dm}^{-3} \mathrm{Mg}\left[\mathrm{B}(\mathrm{HFIP})_{4}\right]_{2} / \mathrm{G} 2$ at a scan rate of $10 \mathrm{mV} \mathrm{s}^{-1}$ at $30{ }^{\circ} \mathrm{C}$. SEM images of the (b) pretreated and (c) pristine metal after CV cycling (10 times). 

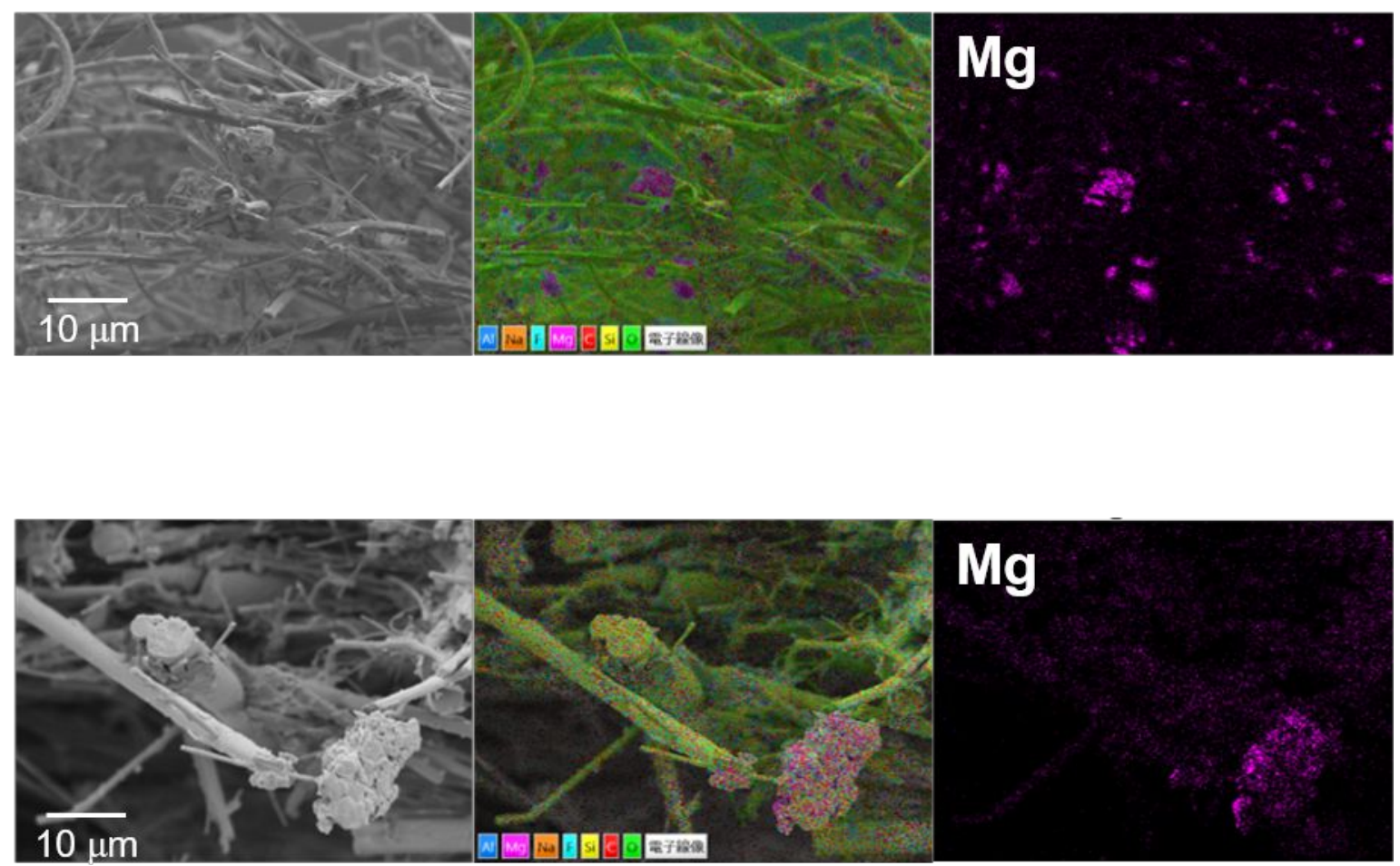

Figure S17. Cross-sectional view and corresponding EDX analysis of GA200 separator retrieved from the [Mg | $\left.0.3 \mathrm{~mol} \mathrm{dm}^{-3} \mathrm{Mg}\left[\mathrm{B}(\mathrm{HFIP})_{4}\right]_{2} / \mathrm{G} 3 \mid \mathrm{Cu}\right]$ cell cycled for 100 times. Current density: $0.5 \mathrm{~mA} \mathrm{~cm}{ }^{-2}$, current application time: $30 \mathrm{~min}$ of deposition/dissolution, temperature: $30{ }^{\circ} \mathrm{C}$. 

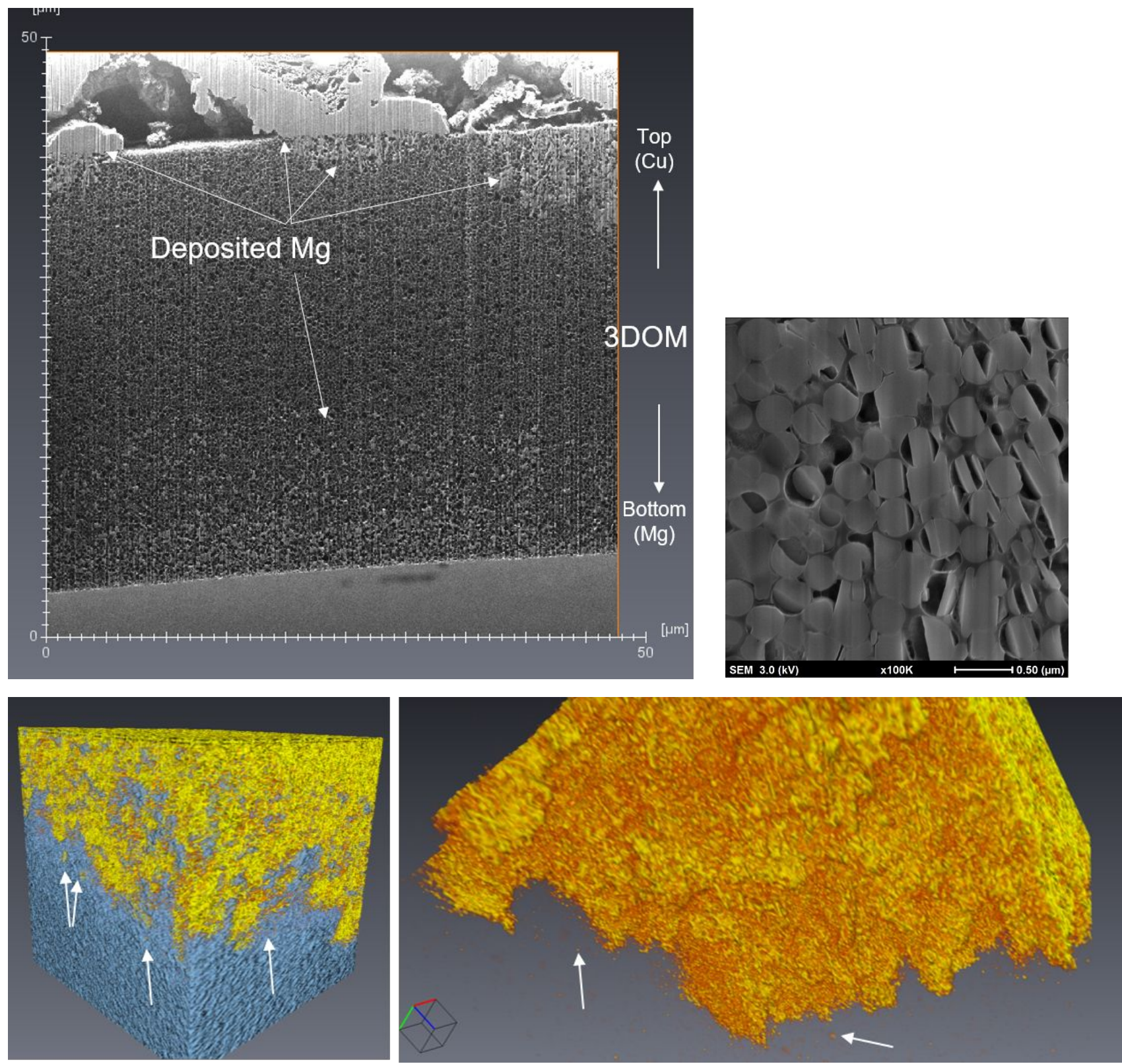

Figure S18. (upper) Cross sectional view and (lower) 3D EDX mapping of 3DOM separator retrieved from the $\left[\mathrm{Mg}\left|0.3 \mathrm{~mol} \mathrm{dm}^{-3} \mathrm{Mg}\left[\mathrm{B}(\mathrm{HFIP})_{4}\right]_{2} / \mathrm{G} 3\right| \mathrm{Cu}\right]$ cell cycled once. Current density: $0.5 \mathrm{~mA} \mathrm{~cm}{ }^{-2}$, current application time: $30 \mathrm{~min}$ of deposition/dissolution $\left(0.25 \mathrm{mAh} \mathrm{cm}^{-2}\right)$, temperature: $30{ }^{\circ} \mathrm{C}$. In the 3D EDX mapping, carbon and magnesium are displayed as gray and yellow-orange color, respectively. Isolated magnesium deposition (highlighted as arrows) is clearly observed in the 3D EDX mapping. 


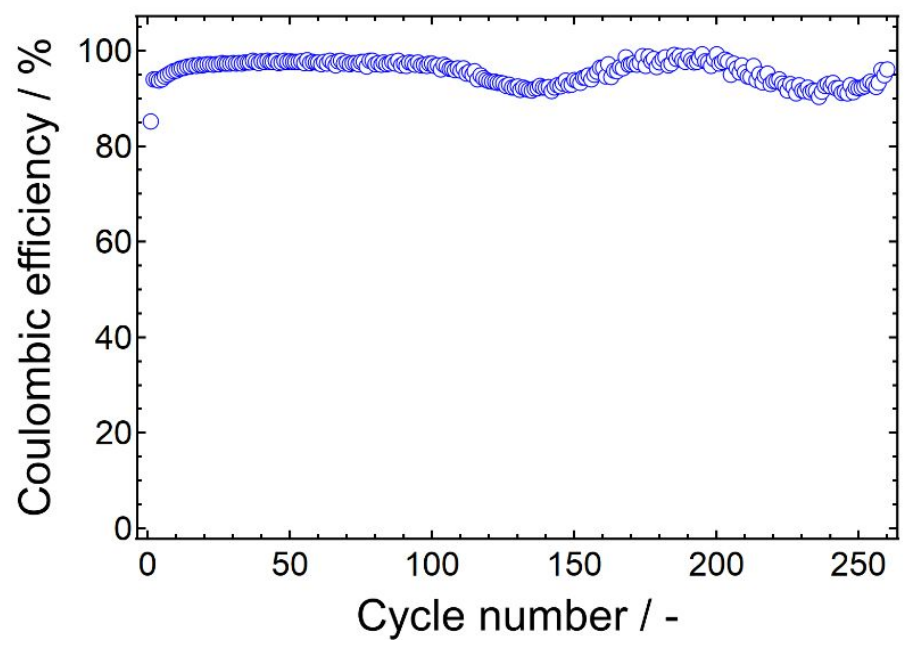

Figure S19. Galvanostatic deposition/dissolution cycling of $\left[\mathrm{Mg}\left|0.3 \mathrm{~mol} \mathrm{dm}^{-3} \mathrm{Mg}\left[\mathrm{B}(\mathrm{HFIP})_{4}\right]_{2} / \mathrm{G} 2\right| \mathrm{Cu}\right]$ cell using GA200 separator. The cycling tests were carried out at a current density of $0.5 \mathrm{~mA} \mathrm{~cm}{ }^{-2}$ and $30{ }^{\circ} \mathrm{C}$. 

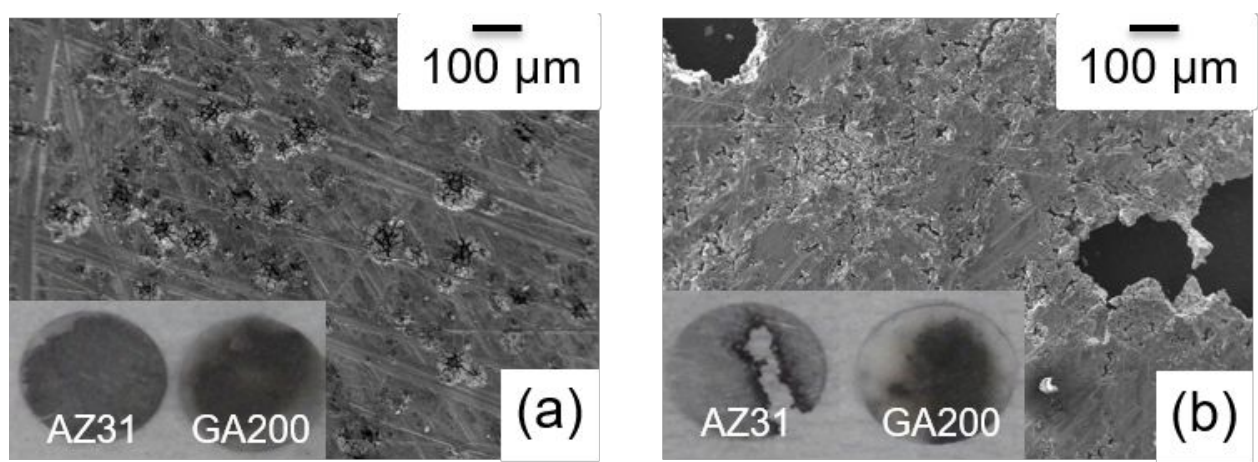

(c)

- At lower temperature
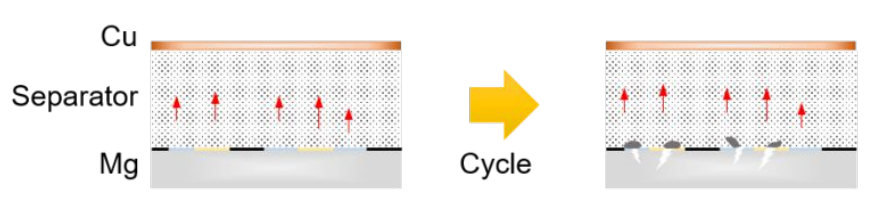

- Passivated

- Moderately passivated

Both highly and moderately active sites are utilized.

- Highly active

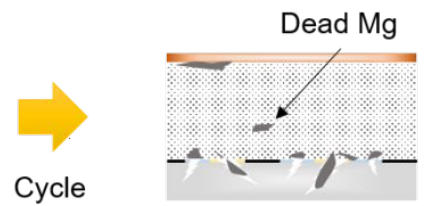

$\rightarrow$ Mass flow

- At higher temperature
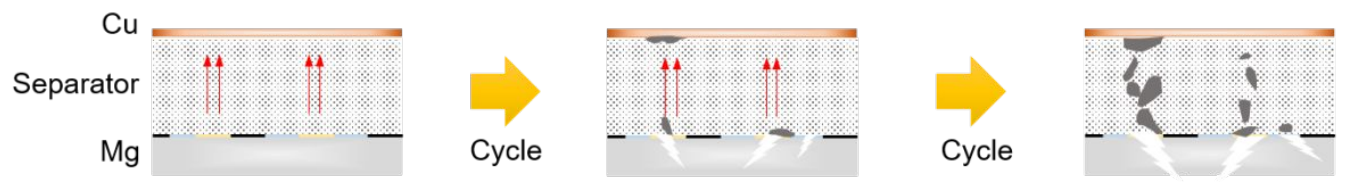

Highly active "hot spots" are utilized preferentially.

Poor affinity and limited, uneven utilization can cause penetration of magnesium. Isolated, dead particles can also lead to short-circuit on the dissolution sites. Some parts are isolated due to poor affinity.

Figure S20. SEM images of the cycled AZ31 retrieved from the $\left[\mathrm{Mg}\left|0.3 \mathrm{~mol} \mathrm{dm}^{-3} \mathrm{Mg}\left[\mathrm{B}(\mathrm{HFIP})_{4}\right]_{2} / \mathrm{G} 3\right| \mathrm{Cu}\right]$ cell cycled at (a) 30 and (b) $60{ }^{\circ} \mathrm{C}$. Digital images are also included. (c) Illustration of possible mechanism of exacerbated uneven utilization at higher temperature. 

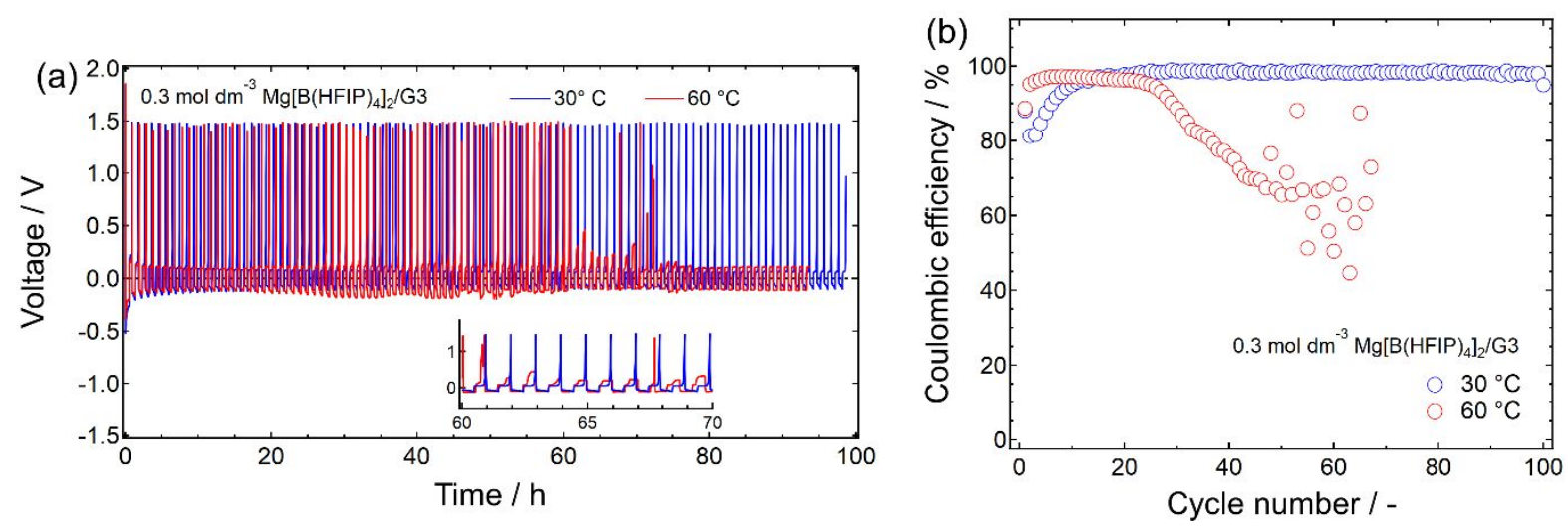

Figure S21. (a) Galvanostatic deposition/dissolution cycling and (b) Coulombic efficiency of $[\mathrm{Mg} \mid 0.3 \mathrm{~mol}$ $\left.\mathrm{dm}^{-3} \mathrm{Mg}\left[\mathrm{B}(\mathrm{HFIP})_{4}\right]_{2} / \mathrm{G} 3 \mid \mathrm{Cu}\right]$ cells. The cycling tests were carried out at a current density of $0.5 \mathrm{~mA} \mathrm{~cm}^{-2}$ and 30 or $60^{\circ} \mathrm{C}$. 